Данута Наугольник

danuta.naugolnyk@gmail.com

\title{
Категорія нижчої міфології в системі світоглядних уявлень карпатських українців
}

\begin{abstract}
Naugolnyk Danuta, Katehorija nyžčoj mifolohiji v systemi svitohladnyx ujavleń karpatśkix ukrajinciv ('Lesser Mythology' in the Carpathian Ukrainians' System of Worldview Notions). „Poznańskie Studia Slawistyczne” 3. Poznań 2012. Adam Mickiewicz University Press, pp. 261-274. ISBN 978-83-232-2473-0. ISSN 2084-3011.

'Lesser mythology' played an important role in the worldview notions of the Carpathian Ukrainians (Hutsuls, Boykos and Lemkos) during the nineteenth and twentieth centuries. It combines notions about various demonic figures, which may be divided into three types: figures of unearthly origin; transformed human souls; people in possession of secret knowledge and supernatural qualities. The terms used to define the representatives of lesser mythology varied from region to region. A range of euphemisms was also used. The coexistence between the living and the undead gave rise to many taboos relating to magic.
\end{abstract}

Keywords: lesser mythology, demon, category, character, figure, dialect, word, title, term, adjective

1. Категорія нижчої міфології у структурі світоглядних уявлень карпатських українців (гуцулів, бойків та лемків) XIX - XX ст. відігравала надзвичайно важливу функцію.

У статті буде охарактеризовано вірування у найважливіших персонажів нижчої міфології, поширених на території всього карпатського ареалу; буде показано властивості демонічних персонажів, способи їхньої появи, захисту від них та методи усунення, а також слова, що вживались на окреслення цих персонажів.

2. У науковий обіг таке поняття впровадив німецький етнограф Вільгельм Маннгардт, який першим почав займатись вивченням цієї категорії міфологічних персонажів ${ }^{1}$. Поняття нижчої міфології доволі

${ }^{1}$ В. Иванов, Низшая мифология, в: Мифы Народов Мира, т. II, ред. С.А. Токарев, Москва 1982, с. 215. 
збірне і широке. Воно охоплює комплекс уявлень про міфологічні істоти, що не мають божественного статусу: демонів, духів, нечисту силу, а також людей, наділених надприродними властивостями. Свою назву категорія отримала завдяки тому, що iï персонажі протиставлялись офіційному міфологічному пантеонові. Характерною ознакою нижчої міфології була сильна віра у іï персонажів та міцний зв'язок із побутовою магією. Завдяки цій властивості вірування у деяких представників категорії у вигляді забобонів побутують і сьогодні.

У традиційному світогляді космос був поділений на три сфери функціонування: небесну, тобто уявну, земну та підземну. Відповідно до цього поділу можна виділити і три групи персонажів, що входили до складу категорії нижчої міфології і були почергово зв'язані із кожною сферою. До першої групи належать постаті неземного походження (серед них найважливіше місце займали персонажі, на означення яких вживались слова: чорт, летавець, чугайстер, блуд). Наступну групу демонологічних персонажів становлять постаті, що є перетвореними людськими душами (на їх означення використовували такі слова як опир, лісна, нявка, бісиця, стратче, мамун, богинка, потопельник, мара). Ці істоти були пов'язані між собою у той спосіб, що мали подвійну природу, тобто одночасно належали до раціонального світу людей та ірраціонального світу надприродних сил. 3 одного боку, вони мали цілком людські якості, функції, риси, з іншого - володіли надприродними якостями ${ }^{2}$. Саме тому більшість міфологічних персонажів, які належали до цієї групи, можна означити терміном дводушник, тобто постать, що одночасно мала людську та демонічну природу.

До останньої групи можна зарахувати людей, що володіли таємними знаннями та надприродними властивостями. Це так звані непро́сті, яких, в свою чергу, поділяли на корисних, що отримували свою силу з Божої благодаті (окреслювались назвами знахар, примівник, баїльник, віжлун, ворожбит, градівник) та шкідливих, які черпали сили від нечистого (персонажі нижчої міфології, що отримали назви відьма, вовкун, місячник, чинатар, сточник).

\footnotetext{
${ }^{2}$ Ю. Буйських, Образ дводушника в системі „нижчої міфологї̈” українців, <vuzlib.com/content/view/1566/62/> [доступ: 1.05.2011].
} 
3. Перші розвідки на тему міфології та демонології етнічного населення української частини Карпат з'явились ще в середині XIX ст. Це були частини праць Івана Вагилевича, Софрона Витвицького та Раймунда Кайндля ${ }^{3}$.

На окрему увагу заслуговує праця Р. Кайндля „Гуцули: їх життя, звичаї та народні перекази”. Автор висвітлив різні аспекти матеріальної та духовної культури Гуцульщини, понадто буковинської та галицької ії частин. Праця складається з 17 розділів. Особливу цінність для даної статті мають три розділи: „Чорти і примари”, „Чаклунство”, „Цілительство”.

Наукового характеру дослідження демонології етнічного населення українських Карпат набрало після створення Наукового Товариства імені Шевченка у Львові (далі - НТШ). Етнографічна комісія, створена у його межах, започаткувала власну серію видань 3 міфології та етнографії. У цьому контексті слід виокремити „Етнографічний збірник" (свого часу редагований Іваном Франком ${ }^{4}$ ), кожен наступний том якого мав власну тематику. У такий спосіб з'явились „Етнографічні материяли з Угорської Руси”, „Галицькі народні казки”, „Галицько-руські народні лєгенди”, „Знадоби до галицько-руської демонольогіи,

Під керівництвом Етнографічної комісії НТШ та заголовком „Материялів до українсько-руської етнольогіі”' була видана і п'ятитомна праця Володимира Шухевича під назвою „Гуцульщина”,. У цьому

${ }^{3}$ І. Дмитрук, Сімейна обрядовість гуиулів в етнографічних дослідженнях кіния XIX - першої половини XX cm., „Гілея. Науковий вісник” вип. 16, 2008, <hklib.npu. edu.ua/full_txt/gilea/gilea16-2008.pdf> [доступ: 21.07.2011].

${ }^{4}$ I. Франко, Людові вірування на Підгірю, в: Етнотрафічний збірник, т. V, ред. I. Франко, Львів 1898, с. 160-218.

${ }^{5}$ Етнотрафічні материяли з Угорської Руси, т. I, зібрав. В. Гнатюк, Львів 1897, <http://elib.nplu.org/view.html?id=306> [доступ: 20.07.2011].

${ }^{6}$ Галицькі народні казки, зібрав О. Роздольський, Львів 1899, <http://elib.nplu. org/view.html?id=99> [доступ: 20.07.2011].

7 Галицько-руські народні лєтенди, зібрав В. Гнатюк, Львів 1902, <http://elib. nplu.org/view.html?id=162> [доступ: 20.07.2011].

${ }^{8}$ Знадоби до галицько-руської демонольотії, зібрав В. Гнатюк, Львів 1904.

${ }^{9}$ В. Шухевич, Гуиульщина, в: Материяли до украӥнсько-руської етнольотї, т. I-V, Львів 1899-1908. 
дослідженні була здійснена спроба опису різних аспектів матеріального та духовного життя гуцульської частини Карпат. У третьому томі В. Шухевич подав докладний опис весільної, похоронної обрядовості, а також опис хрестин. Четвертий том містить описи церковних обрядів та звичаїв, пов'язаних з церковним календарем. П'ятий том, у свою чергу, охоплює матеріали про народну медицину, опис вірувань про рослини і тварин, перекази про земних богів тощо.

Приблизно тоді ж Етнографічна комісія НТШ почала видавати „Матеріяли до української етнольогіі”, на сторінках яких друкували свої дослідження 3 міфології та демонології Володимир Гнатюк ${ }^{10}$ та Антін Онищук ${ }^{11}$.

У 1912 році під редакцією В. Гнатюка вийшов в світ кількатомник „Знадоби до української демонольогіï”, в якому містились описи вірувань у різні постаті нижчої міфології, поміж іншим, чорта, упиря, вовкуна, відьму тощо. В. Гнатюк також $\epsilon$ автором „Нарисів української міфології”, репринт якої був виданий у Львові у 2000 році ${ }^{12}$.

Долучився до досліджень над міфологічними уявленнями також антрополог Хведір Вовк. Свого часу він редагував вже згадувані „Материяли до українсько-руської етнольогії, а у праці „Студії 3 української етнографії та антропології”,13 окрему увагу приділив опису гуцульської обрядовості.

Слід згадати і про науковий доробок польських краєзнавців та етнографів межі XIX та XX ст. Інформація на тему міфологічних уявлень карпатських українців міститься у працях Антоні Шнайде$\mathrm{pa}^{14}$, Леопольда Вайгеля ${ }^{15}$, Яна Фальковського ${ }^{16}$. На величезну увагу

10 В. Гнатюк, Купанє й палєнє відьм в Галичині, в: Матеріяли до украйнської етнольотї, т. XV, Львів 1912, с. 178-201.

11 А. Онищук, Матеріяли до гуцульської демонольотії. Записані у Зеленици, надвірнянського повіта, 1907-1908, в: Матеріяли до української етнольотї, т. ХІ, Львів 1909, c. $1-139$.

12 В. Гнатюк, Нарис української міфологї, Львів 2000.

${ }^{13}$ Хв. Вовк, Студї̈ з української етнографії та антропології, Київ 1995.

${ }^{14}$ A. Schneider, Z kraju Hucułów, „Lud” t. V, 1899, c. 57-62, 147-154, 207-220, 336345; t. VI, 1900, c. 157-160, 257-267, 351-361; t. VII, 1901, c. 65-73, 169-176, 259-271.

${ }^{15}$ L. Wajgel, O Hucułach, „Pamiętnik Towarzystwa Tatrzańskiego” t. II, 1887, c. 49-86.

${ }^{16}$ J. Falkowski, B. Pasznycki, Na pograniczu temkowsko-bojkowskiem, Lwów 1935. 
заслуговує феноменальний доробок Станіслава Вінценза, об'єднаний у роман-трилогію „На високій полонині”. У цій праці автор на основі величезного етнографічного матеріалу зобразив побут і духовну культуру гуцулів. Український переклад першої частини роману з'явився у 2011 році $^{17}$.

Новий етап досліджень даної тематики розпочався вже після Другої світової війни. Характерною рисою цього періоду було збільшення уваги до вивчення матеріальної культури. Посеред праць того періоду слід відзначити дослідження М. Мандибури „Полонинське господар-

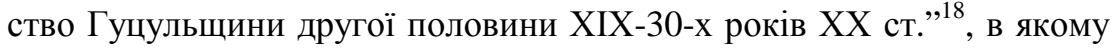
можна віднайти опис обрядодій, пов'язаних із вірою в нечисту силу.

Узагальнюючий характер мали праці, присвячені Бойківщині ${ }^{19}$ та Гуцульщині ${ }^{20}$, в яких окрім аналізу аспектів матеріального життя регіону можна віднайти короткий аналіз проблем духовного світу.

Варто відзначити також доробок польських дослідників у галузі вивчення етнографії та міфології українських Карпат а серед них праці Р. Реінфуса про історію, побут та духовну культуру лемків ${ }^{21}$.

Проголошення незалежності України започаткувало новий етап етнографічних досліджень, що характеризується розширенням діапазону наукових зацікавлень, а також збільшенням кількості тематичних видань. Тут слід відзначити доробок українського дослідника та художника В. Войтовича, з-під пера якого вийшов ряд праць, присвячених українській дохристиянській міфології - народним віруванням, а в тому числі звичаям та обрядам ${ }^{22}$.

4. Найпопулярнішим персонажем нижчої міфології мешканців українських Карпат без сумніву був персонаж, що окреслювався назвою чорт. Вірилось водночас у цілу систему чортівської ієрархії.

${ }^{17}$ С. Вінценз, На високій полонині, Івано-Франківськ 2011.

${ }^{18}$ М. Мандибура, Полонинське господарство Гуцульщиини другої половини XIX30-х років ХХ ст. Історико-етнографічний нарис, Київ 1978.

${ }^{19}$ Бойківщина: Історико-етнографічне дослідження, відп. ред. Ю.Г. Гошко, Київ 1983.

${ }^{20}$ Гуиульщина: Історико-етнографічне дослідження, відп. ред. Ю.Г. Гошко, Київ 1987.

${ }^{21}$ R. Reinfuss, Śladami Łemków, Warszawa 1990.

${ }^{22}$ В. Войтович, Українська міфологія, Київ 2002. 
Очолював іï найстарший чорт, який отримав окрему назву - арідник. На нижчих щаблях розташовувались звичайні чорти. Особливістю вірувань у чорта було те, що на його означення вживалась велика кількість евфемізмів. На означення арідника - триюда, юда, сатана, ірод, біда, підвладних йому чортів - він, клопотник, нечістий, осинавець, пекун, скуса, щезник. Ці назви з'являлись для того, щоб уникнути вживання слова чорт ${ }^{23}$.

Існувала велика кількість обмежень, яких слід було дотримуватись, аби вберегти себе від згубної дії демонічних істот. До прикладу, не варто було згадувати чорта в хаті з малими дітьми (хіба що перед тим слід було промовити: „Дух святий при дитині”), а також при тяжкій роботі чи вночі. Не годилося ввечері дивитись у дзеркало, бо можна було видивитись у ньому чорта. Заборонялось свистіти проти ночі, бо чорт міг прийти і запитатись: „Чого хочеш? Чого мене кличеш?". Майже неможливо було знайти хати, де б посудина 3 водою не була накрита кришкою чи тканиною, щоб бува нечистий не вліз досередини ${ }^{24}$. Не варто було зачіпати старі занедбані хати та печі, а під час грози - ховатись під дубом чи вербою, ,де є житло чорта і куди він найчастіше ховається" від неї ${ }^{25}$.

Чортові надавали тваринних і людських рис, властивостей неживих предметів. Вірилось, що чорти зазіхали на людську душу, намагались спокусити людину до гріха, завдавали збитків, спричиняли сильний вітер.

Наступне місце в ієрархії нечистої сили займав домашній чорт, або ж як він ще називався хованець. На означення домашнього чорта у різних місцевостях використовували різні слова. До прикладу, лише у п'яти селах Сколівського району Львівської області (етнографічна Бойківщина) дослідниці Надії Левкович вдалось зафіксувати майже два десятки імен, що використовувались на означення домашнього

23 Э. Померанцева, Мифологические персонажи в русском фольклоре, Москва 1975, c. 132.

${ }^{24}$ С. Максимов, Нечистая, неведомая и крестная сила, Санкт-Петербург 1994, c. 151 .

${ }^{25}$ Р. Сілецький, Вибір будівельного матеріалу в украӥнців (заборони, прикмети, звичаї, повір'я), „Вісник Львівського Університету. Серія історична” вип. 37/1, 2002, c. 529 . 
чорта. Серед них: хованець, годованець, вихованець, плеканчик, Панько, Юрко, Іванцьо, господар, слуга, лілік, той, що з ріжками, чорт, дідько, той нечистий, пек би му, помочнік, той гобрусь ${ }^{26}$.

Домашнього чорта можна було собі купити. Для цього, купуючи якийсь товар, слід було сказати фразу: „Купую зі всім”. Хованець був зобов’язаний прислуговувати своєму господареві до старості, допомагати йому при газдівстві а деколи - приносити сусідське майно. Господарка сусідів натомість занепадала 27 . При бажанні можна було мати кількох хованців - для різних видів робіт. Коли людина помирала, багатство швидко безслідно зникало ${ }^{28}$. Смерть такої людини була дуже важкою: за віруваннями гуцулів, хованець відносив душу свого господар у пекло і віддавав найстарішому дияволу. Той запихав душу у яйце, 3 якого вилуплювався ще зліший дух ${ }^{29}$.

Домашнього чорта можна було собі виховати. Для цього яйце, яке на Благовіщення знесла чорна курка, слід було тримати під пахвою впродовж дев’ яти діб. У той час людині було заборонено вмиватись, хрестити, молитись, постити. На Бойківщині яйце клали під пахву із таким розрахунком, щоб дев' ятий день припав безпосередньо на Великдень. У тому випадку, людина, що виношувала хованця, у той момент, як в церкві вперше співали Христос Воскрес, мала промовити: „І мій воскрес”.

Неземне походження в уявленнях карпатських українців мав демон, що окреслювався терміном летавець (інші назви - летун, летавиця, в інших регіонах України вживалась назва перелесник).

Демон приходив до молодих дівчат у вигляді гарного юнака, закохував їх у себе, вступивши у фізичний контакт, позбавляв сил і життя. Для захисту від летавця дівчина мала постійно носити при собі часник. Жіночим відповідником була летавиця: нечиста сила, що вночі ховалась у гіллі дерев і своєю красою приваблювала нічних

\footnotetext{
${ }^{26}$ Н. Левкович, Домовик (,годованець”) у демонологічних уявленнях бойків Сколівщини, в: Етнічна культура украӥнців, ред. В. Галайчук, Львів 2006, с. 217.

27 В. Галайчук, Демонологічна палітра бойків Старосамбірщини. Вірування в домашніх духів (На польових матеріалах), в: Етнічна культура украйниів, ред. В. Галайчук, Львів 2006, с. 200.

${ }^{28}$ I. Франко, ор. cit., c. 210.

${ }^{29}$ В. Войтович, op. cit., c. 157.
} 
перехожих. На ногах мала червоні чобітки, за допомогою яких могла літати над землею. Зникала зі сходом сонця ${ }^{30}$.

Неземне походження мав також чугайстер (інша назва - вітровий дідо). За віруваннями карпатських українців цей дух мав вигляд чоловіка зі зростом приблизно у кільканадцять метрів у білому одязі або ж навпаки - без одягу, але 3 порослою волоссям шкірою. До людей чугайстер ставився приязно, натомість знешкоджував нявок.

Слово блуд у говірках карпатських українців вживалось у значенні нечистої сили, що мала здатність збивати з правильної дороги. За віруваннями лемків і бойків блуд чіплявся передовсім людей п'яних, непобожних і забобонних.

Якщо пастух зустрічав цього демона, потрібно було „єму єк си покажет потопленик ци повішеник, узети руки назад и сказати: шо перше на небі, шо друге - двоє очів в голові, шо третє - трійця в церкві, шо четверте - штири колеса воза, шо п'єте - п'ять пальців на руках, шо шосте - курашка на небі, шо семе - де $\epsilon$ сім дівок, своя вечерниця, шо $є$ восьме, - де $є$ вісім хлопців, - свої косарі, шо дев'єте - за девіть грейцарів купив у дурня вепря". Після цих слів злий дух мав розсердитись і сказати: „На ше тобі запрашки до юшки”, рилось також, що коли до людини вчепився блуд, то „тра собі нагадати, у котрий день буў Сьвитвечір і якї сі страви їло,

На межі поміж нечистою силою та людьми у віруваннях карпатських українців перебував демон, що у місцевих говірках окреслювався назвою опир. Опирі насилали стихійні лиха, пошесті, засухи, повені. До худоби опирі сили не мали, тільки до людей. Могли сідати людям на плечі й переслідувати їх аж до хатнього порога, а самого порога вони боялися ${ }^{33}$.

На Лемківщині побутувало повір'я, що опирі вставали з могили коли сумували за родиною. У такому випадку вони повертались до-

${ }^{30}$ Слов'янський світ. Ілюстрований словник-довідник міфологічних уявлень, вірувань, обрядів, легенд та їхніх відлунь у фольклорі і пізніших звичаях украӥнців, братів-слов'ян та інших народів, упор. О. Кононенко, Київ 2008, с. 246.

${ }^{31}$ М. Мандибура, op. cit., с. 167.

32 Знадоби до української демонольотї̈, т. II, вип. 1, зібрав В. Гнатюк, в: Етнографічний збірник, Львів 1912, с. 209.

${ }^{33}$ В. Войтович, ор. cit., с. 550. 
дому і допомагали родині при газдівстві. Вірилось і в те, що опирями могли бути жінки, які помирали при пологах, а потім вставали вночі 3 могили, щоб годувати і купати своїх дітей ${ }^{34}$.

Значення слова опир розширювалось за допомогою використання прикметників-конкретизаторів: родимий і роблений. Родимого демона легко розпізнавали за тим, що він мав червонуватий відтінок шкіри. Лемки були переконані, що родимі опирі мали зрощені посередині брови, а після смерті - еластичне тіло і рожевого кольору шкіру. Окрім того, після смерті у них продовжували рости нігті. На Покутті побутувала думка, що опирі були безплідними і саме цим вирізнялись 3-посеред звичайних людей.

Коли опир помирав, то починалась сильна злива. На Гуцульщині демона ховали лицем до землі (щоб він не бачив місячного світла), головою на схід, а священик мав запечатати гріб в головах та ногах так, аби опир не міг вийти з могили.

Цікавою групою постатей в нижчій міфології карпатських українців були жіночі демони. У говірках українців Карпат вони отримали такі назви як лісна, нявка, бісиця, мамун, богинка. Із цієї групи міфологічних персонажів передовсім слід розглянути категорію лісної нечистої сили у вигляді дівчини з отвором у спині, що зваблювала молодих чоловіків і зводила їх зі світу. У гуцульських говірках було поширено кілька синонімів назви цього демона, таких як лісниця, лісовиця, а подекуди - лісовка. Вірилось, що ці демони утворювались iз душ померлих неохрещених дітей, яких матері таємно хоронили у лісі. Карпатські українці вірили, що лісні збирались на полонинах i танцювали у незамкненому колі. Згодом на таких місцях після сходження снігу виростали рясні трави.

Подібні характеристики мали нявки, адже виглядали вони і з'являлись у такий же спосіб як і лісні. Вірилось, що нявки мешкали у гірських печерах, прикрашених килимами, а на щодень нявки пряли крадений льон, ткали та шили одяг з вибіленого полотна. Танцювали нявки парами. Вважалось, що до танцю нявкам грав на дудці (або ж козі) чорт, а ті в свою чергу співали: „Бодай мама не прощена, /Що я умерла не хрещена!"35. На тому місці, де хоч раз танцювали нявки,

${ }^{34}$ R. Reinfuss, op. cit., c. 88.

${ }^{35}$ А. Онищук, op. cit., с. 56. 
ніколи вже не могла вирости трава. Такі місця гуцули, наприклад, називали ігровищами. А пастухи, що випадково переступали межі ігровищ, поступово втрачали сили та помирали. Боялись нявок через те, що ті зваблювали юнаків, вели їх на роздоріжжя та лоскотали до смерті. Вважалось, що нявки пили кров своїх жертв.

Постатями, подібними до нявок, в нижчій міфології українців Карпат були бісиці. На Гуцульщині цю назву вживали також на окреслення чортиць. С. Вінценз у своїй праці „На високій полонині” так окреслював цю демонічну постать: „Із туги з'явиться бісиця, постане у вигляді зажуреної жінки, і запровадить одразу на саме дно зими ${ }^{\text {"36. }}$

Дуже подібні властивості мала категорія під назвою стратче (синонім - збіглєнє, в інших регіонах України - потерча), тобто дух неохрещеного чи убитого матір'ю немовляти. Ці демони з'являлись у такий же спосіб як і нявки, завдавали всілякої шкоди людям, аби привернути до себе якомога більше уваги.

Наступна підгрупа постатей нижчої міфології поєднує п'ять персонажів, які залежно від обставин та території могли або ототожнюватись, або навпаки - протиставлятись. Слід виокремити передовсім категорію, що в етнографічних записах зустрічалась під назвою мамун (паралельна назва на Гуцульщині та Бойківщині - дика баба). Демон поставав у вигляді високої худої старшого віку жінки з довгим закуйовдженим волоссям. Мамуни боялися світла, а тому мешкали у непролазних хащах над водою і болотами. У гуцулів побутувало переконання, що на мамунів перетворювались жінки, які помирали під час вагітності чи пологів. Ці демони захоплювали породіль, що порушували заборону покидати хату перед виводом, водили їх бездоріжжями, змушували до танцю, могли залоскотати свою жертву до смерті $^{37}$. На Бойківщині побутувало уявлення, що той, хто зловить мамуна, отримає найвірнішу наймичку. Бойки часто лякали дітей дикою бабою, аби ті не робили збитків ${ }^{38}$.

${ }^{36}$ S. Vincenz, Na wysokiej połoninie, t. II, Nowe czasy - Zwada, Sejny 2003, c. 260.

37 У. Яніцька-Кшивда, Дивні полонини (про гуцульську демонологію), в: Гуиули, бойки, лемки - традииія і сучасність. Матеріали наукової конферениії, Краків 2008, c. 87.

${ }^{38}$ Ф. Колесса, Людові вірування на Підгірю. В с. Ходовичах стрийського повіту, в: Етнотрафічний збірник, т. V, ред. І. Франко, Львів 1898, с. 94. 
Боялись мамунів насамперед тому, що ті обмінювали людських дітей на власних. Ці демони отримали назву підміна (відміна) і характеризувались тим, що мали маленьку голову, довгі вуха, тонкі ноги, великий живіт. Підміна часто хворіла, погано розвивалась, постійно галасувала і вимагала їсти. Аби позбутись підміни, слід було винести іiі на межу в місячну ніч і там бити терновою різкою. Тоді демон мав пожаліти власну дитину і зробити повторний обмін.

До цієї підгрупи демонічних персонажів належали також богинки, віра в яких побутувала переважно на території Лемківщини. Демони із такою назвою, за переказами лемків, поставали з душ померлих прачок і набували вигляду старих бридких жінок, що вночі на річках і потоках прали білизну за допомогою власних грудей ${ }^{39}$.

Важливою постаттю в системі нижчої міфології карпатських українців був, поміж іншим, потопельник. У говірках карпатських українців назва цього представника нижчої міфології зустрічається 3 невеликими відмінностями у різних місцевостях, але всюди вона має однаковий корінь і однакове значення. Назва вживалась на позначення душі утопленика, що блукала в місці своєї загибелі до того моменту, доки не призведе до смерті іншої людини у тому ж місці і в такий же спосіб. Лишень у такий спосіб душа могла відкупитись.

Подібні властивості мав і такий міфологічний персонаж, на позначення якого у говірках українців Карпат вживається слово мара. У мару перетворювалась душа вівчаря, вбитого на полонині. Демон перебував у місцях загибелі вівчарів, що мали назву сокровищ, і переступати їх було заборонено: худоба могла захворіти, а на людину напасти демон.

Якщо говорити про непро́стих, до корисних можна зарахувати персонажів, які в говірках отримали такі назви: знахар, примівник, баїльник, віжлун, ворожбит, градівник.

Знахар лікував людей і тварин за допомогою зілля. Якщо таке лікування не було надто ефективним, тоді варто було звернутись по допомогу до примівника. Головним інструментом примірника було слово у формі примівок та замовлянь. У цій ієрархії він перебував вище, ніж знахар.

\footnotetext{
${ }^{39}$ R. Reinfuss, op. cit., c. 86.
} 
У говірках західної частини Гуцульщини властивості знахаря і примівника були перекладені на баїльника. Вірилось, що баїльники можуть допомогти при хворобі, а також „замовити” людину від зміїного укусу. Свої знання вони зазвичай отримували від котрогось із родичів, вивчивши напам' ять спеціальне замовляння.

У гуцульських говірках зафіксовано назву віжлун. Ї̈̈ вживали на означення людини, що могла передбачати майбутнє. Від віжлуна не можна було приховати жодної інформації, він міг читати думки людей. Персонаж нижчої міфології, окреслений назвою ворожбит, на відміну від віжлуна міг не тільки пророкувати майбутнє, але й вгадувати минуле.

До корисних непро́стих належав також градівник (у бойківських говірках були поширені назви планітник, хмарник та градобурник), який за допомогою спеціальних заклять і молитов міг відвертати град, зупиняти бурю чи відводити іiі у нешкідливе місце.

Перше місце в категорії шкідливих непро́стих належало відьмі. Ця назва була поширена була не лише в говірках, а й в літературній мові. Понадто, що саму лексему відьма зі значенням 'відьма, чаклунка' зафіксовано в пам'ятках української мови з XVI століття ${ }^{40}$. Вірилось, що відьми - це звичайні жінки, обдаровані надприродною силою.

Залежно від походження відьом поділяли на дві категорії, окреслювані прикметниками-конкретизоторами: родимі і вчені. Родима відьма могла з'явитись у такій сім'ї, де було семеро дітей, а 3-поміж них - не було жодного хлопця. Вважалось, що вчені відьми були злішими і навчались ремеслу від родимих. Від родимих різнились тим, що до корів по молоко ходили 3 дійницями ${ }^{41}$.

Відьми мали свою спеціалізацію. Найнебезпечнішими вважались ті, що „потинали” - забирали в худоби молоко і чинили шкоду людям. Від iї погляду людині „можна навіть усохнути”“2. Днем найбільшої активності відьом було свято Юрія Змієборця: день, коли вівчарі вперше після зими виводили худобу на полонину. Тоді відьми зби-

${ }^{40}$ Н. Хобзей, Гуцульська міфологія: етнолінгвістичний словник, Львів 2002, с. 58.

${ }^{41}$ Хв. Вовк, ор. сit., с. 179.

${ }^{42}$ М. Влад, Стрітеннє: Книжка гуиульських звичаїв і вірувань, Київ 1992, с. 157. 
рались на „круглїках (горбок на пасовиську о помірі 2-3 м),"43, де влаштовували забави.

Відьму можна було знешкодити. Для цього слід було просто сказати їй у вічі: „осове кіло в серце”. Після цього вона мала б втратити свої сили. Відьма позбувалась своїх здібностей також тоді, коли зізнавалась у своїх лихих діях. Обряди, пов'язані зі смертю та похованням відьми, були подібними до обрядів, які здійснювали після смерті опиря.

Не менш цікавою постаттю нижчої міфології українців Карпат був вовкун - персонаж, поширений не тільки в карпатській, а й загальноєвропейській міфології. Синонімом до назви вовкун могло бути і слово вовк.

Вовкуни були двох різновидів: вроджені і зачаровані. Вірилось, що коли вагітна жінка бачила вовка або їла м'ясо тварини, яку роздер вовк, то вона неодмінно мала народити вовкуна. Зачаровані вовкуни проводили більшість часу з вовками, аж до того моменту, поки їх не розпізнавали i не відчаровували. Вбити вовкуна можна було лише срібною кулею, посвяченою в дев'яти церквах, дев'ятьма священиками.

До категорії шкідливих непро́стих зараховували постаті, що в говірках карпатських українців були окреслені назвою місячників. До цієї категорії належали люди, що зі зміною місяця змінювали свою стать. Ця риса була вродженою, але вплив на це мали хрестини. Адже якщо народиться дівчинка, i ,священик намастить іiі жіночим миром, це буде жінка і лише перетворюватись буде в чоловіка, а коли народиться хлопець, і священик намастить його „чоловічим миром”, то той буде перекидатись в жінку ${ }^{44}$.

Шкідливими непро́стими у нижчій міфології карпатських українців були також чинатарі - люди, що за допомогою чарів могли наслати хвороби, сварки та незгоду. Чергові постаті з цієї категорії названі сточниками, тобто люди, що вміли виконувати будь-яку роботу. Іноді їм надавали також здатність управляти гадюками, вужами, мишами, скликати їх при потребі і на когось насилати ${ }^{45}$.

\footnotetext{
${ }^{43}$ Знадоби до української демонольотї̈, с. 104.

${ }^{44}$ A. Schneider, op. cit., c. 112.

${ }^{45}$ Гуиульщъина..., с. 250.
} 
Віра у різноманітних демонів була невід’ємною частиною світогляду і побуту карпатських українців. Нечисту силу боялись, намагались від неї вберегтись та їй протидіяти. Поряд із обрядодіями, які застосовувались для захисту від демонічних істот, важливу роль відігравало і слово у формі магічних заклинань та заговорювань. 